\begin{tabular}{|l|l|}
\hline Journal of \\
Flood Risk Management
\end{tabular}

\title{
Is Planting Trees the Solution to Reducing Flood Risks?
}

\begin{tabular}{|r|l|}
\hline Journal: & Journal of Flood Risk Management \\
\hline Manuscript ID & JFRM-0101-17.R1 \\
\hline Danuscript Type: & Original Manuscript \\
\hline Complete List of Authors: & $\begin{array}{l}\text { Carrick, Jayne; Newcastle University, } \\
\text { Stewart, Gavin ; Newcastle University } \\
\text { Bolam, Friederike; Newcastle University } \\
\text { Clark, Beth; Newcastle University } \\
\text { Grainger, Matthew; Newcastle University }\end{array}$ \\
\hline Keywords: & Flood mitigation, Integrated flood risk management, Catchments \\
\hline & \\
\hline
\end{tabular}




\section{Is Planting Trees the Solution to Reducing Flood Risks?}

Corresponding Authors:

Jayne Carrick, Newcastle University: jayne.carrick@newcastle.ac.uk

Dr Gavin Stewart, Newcastle University: gavin.stewart@newcastle.ac.uk

Contributing Authors (Family Name, Given Names):

Carrick, Jayne; Bin Abdul Rahim, Mohd Shaiful Azman; Adjei, Cosmos; Ashraa Kalee, Hassan Habib Hassan; Banks, Steven James; Bolam, Friederike Charlotte; Campos Luna, Ivone Maritza; Clark, Beth; Cowton, Jake; Domingos, Israel Freitas Nongando; Golicha, David Duba; Gupta, Garima; Grainger, Matthew, Dr; Hasanaliyeva, Gultakin; Hodgson, David John; Lopez-Capel, Elisa, Dr; Magistrali, Amelia Jo; Merrell, Ian George; Oikeh, Idiegberanoise; Othman, Mwanajuma Salim; Ranathunga Mudiyanselage, Thilanka Kumari Ranathunga; Samuel, Carl Warren Charles; Sufar, Enas KH; Watson, Philip Alexander; Zakaria, Nik Nur Azwanida Binti; Stewart, Gavin, Dr.

All at Newcastle University, Newcastle upon Tyne, Tyne and Wear, NE1 7RU, UK 


\begin{abstract}
Flood risk and associated impacts are major societal and policy concerns following widespread flooding in December 2015, which cost the UK economy an estimated £5billion. Increasing advocacy for alternatives to conventional hard engineering solutions is accompanied by demands for evidence. This study provides a systematic review and metaanalysis of direct evidence for the effect of tree cover on channel discharge. The results highlighted a deficiency in direct evidence. From seven eligible studies of 156 papers reviewed, the results show that increasing tree cover has a small statistically significant effect on reducing channel discharge-and negligible effect on flood risk. Meta-analysis reveals that tree cover reduces channel discharge (standardised mean difference -0.35 , $95 \% \mathrm{Cl},-0.71$ to 0.00$)$, but the effect was variable $\left(\underline{I}^{2}=81.91 \%\right)$, the potential for confounding was high, and publication bias is strongly suspected (Egger Test $z=3.0568, p=0.002)$. Due to the lack of direct evidence the overall strength of evidence is low, indicating high uncertainty. Further primary research is required to understand reasons for heterogeneity and reduce uncertainty. A Bayesian network parameterised with data from the meta-analysis supports investment in integrated catchment management, particularly on infrastructure density and water storage (reservoirs), for effective responses to flood risk.
\end{abstract}

KEYWORDS: Bayesian network, flood risk, meta-analysis, systematic review, tree cover 


\section{INTRODUCTION}

Flooding poses serious socio-economic threats; 'each year, floods claim approximately 20,000 lives and adversely affect at least 20 million people worldwide' (Kellens et al., 2013, p. 24). Recent studies indicate that losses from flood hazards are expected to increase in coming years, some attributing this to climate change (Kellens et al 2013, p. 24), with the most recent flooding that mainly affected Northern England (Cumbria and Yorkshire) and Scotland during December 2015 estimated to cost the UK economy £5billion (KPMG, 2015). With increasing frequency of extreme flood events in the UK, attention has turned again to methods to reduce flood risk.

There are multiple often conflicting discourses relating to flood risk and associated mitigation measures. Extreme weather events and climate change are considered contributory; lack of control over the weather is often used to justify weak flood protection policy and decision making. However, in reality catchments are complex systems that are disrupted by human habitation, which in itself creates potential for flood impact. Complexity and uncertainty adversely affects decision and policy making, and subsequently, reduces the effectiveness flood risk mitigation measures (O'Connell et al., 2004).

Flood risk mitigation approaches are often divided into three types; 'hard' engineering, 'soft' engineering and passive measures. The 'hard' measures involve physical barriers (reservoirs, dams and embankments), which are often expensive, time consuming, impractical and in some cases, like the floods in December 2015 in the North West of England, they are overwhelmed, where design standards are exceeded. The 'soft' measures include changes in vegetation cover (including forestation), land management, improvements of water channels, improvements of drainage system, and diversions of water ways or rivers (for a full discussion see Wilkinson et al., 2010). Taking passive approaches involves doing little to control flood events and instead diverting investment to compensate victims, improving community awareness of flood risk, and subsidising insurance policies. 
After being the favoured approach, the overwhelming of 'hard' measures during floods of December 2015 in the Northern England shifted attention. The 'hard' defences installed after floods in 2005 in places such as Carlisle, (BBC News, 2010), were overcome. Since this failure, the focus has shifted and renewed appreciation of the complexity of flood risk has led to calls for alternative 'soft' approaches. This includes widespread advocacy for land management approaches to increase the storage capacity of catchment areas and to slow down the water getting into channels, instead of the conventional focus on hard defences that manage water already in the channel (Dixon et al., 2016; Harrabin, 2016b; The Guardian, 2016). Previous research has suggested that modern agricultural land management characterised by non-native, homogenous vegetation cover reduces the storage capacity of catchment areas, reducing lag time, increasing water course discharge and increasing flood risk (CIRIA, 2013). To address this increasing tree cover is advocated as an effective means of increasing the storage capacity of catchment areas to increase the lag time, reduce water course discharge and subsequent flood risk (Dixon et al., 2016).

This study provides an assessment of the effectiveness of soft engineering solutions, specifically that of increasing tree cover to reduce flood risk, to consider whether calls for investment in increasing tree cover to mitigate flood risk is justified. It is anticipated that the effectiveness of increasing tree cover in reducing flood risk is variable; studies have indicated that tree cover is likely to have a smaller effect in larger catchments compared to smaller catchments (less than $10 \mathrm{~km}^{2}$ ), where a significant effect is anticipated (Kirby et al., 1992; CIRIA, 2013). To account for the complexity of the causes of flooding and to account for a holistic approach, the evidence is contextualised in a systems model.

The overall aim of the study is to advance the knowledge base associated with flood risk and impact. Results of existing studies on flood mitigation are combined to evaluate the strength of evidence that tree cover reduces flood risk. A systems model contextualizes the findings to explore the conflicting policy discourses. 
The objectives are:

1. To synthesize the direct empirical evidence on the effectiveness of tree planting for mitigating flood risk by reducing discharge; and

2. To contextualize evidence that tree cover reduces flood risk within a systems model of the wider catchment-scale management options.

\section{MATERIAL AND METHODS}

\section{Systematic Review}

\section{Approach}

A systematic review and meta-analysis were undertaken to assess the direct impact of tree cover on channel discharge in studies from North-Western (NW) Europe.

\section{Search methods for identification of studies}

Separate teams of researchers searched four online databases: ISI Web of Knowledge $(\mathrm{GH}$, ES), Scopus (BC, MO, ICL), Google Scholar (CS, CA) and Google (NZ, ABAR), with the latter two chosen to facilitate the identification of grey literature. Each database was searched with a combination of keywords detailed in Table 1. The search strategy was tailored to each individual database by trialling combinations of keywords relating to the intervention and outcome combined with the Boolean logic operators AND and OR. Search terms were refined after several trial searches to ensure the most effective search terms were used to optimise sensitivity and specificity. Given the volume of search results returned, a full screening of results was not undertaken. Instead the first 100 results from each database were assessed for inclusion_(as ordered by relevance) as per rapid review methodology (inter alia Bernado et al, 2013). Although this limits the potential identification of studies through not screening all returned results, it enables the rapid identification of the most relevant literature. In addition to the database searches, the reference list from Defra's Impact Study Report (O’Connell et al., 2004) was checked for relevant studies.

\section{Selection of studies}


A framing exercise defined the boundaries of the study, specifically, the population, interventions, comparisons and outcomes (PICO) of interest (Koricheva et al., 2013), which informed the eligibility criteria for a two-stage screening process, presented in Table 2. Initially the titles and abstracts were screened to assess eligibility, with full text assessment then undertaken by two independent researchers, this is outlined in the PRISMA flow diagram in Figure 1 (Moher et al, 2009).

\section{Data extraction}

Two groups independently extracted data from the relevant studies. Data were extracted from graphs using GRABIT, MATLAB software (Doke, 2005). The number of samples, the mean discharge in treatment and control site, and the standard deviation were extracted.

\section{Assessment of risk of bias in included studies}

A critical appraisal of the relevant studies was undertaken to independently assess the risk of bias. Each study was assessed against the following questions, scoring 1 for yes and 0 for no responses.

These were;

1. Have the meteorological factors been considered as confounders or controlled for in study design?

2. Have the land use factors been separated?

3. Have the topographical factors been separated?

4. There are no stated conflicts of interest?

5. Are all measurements and outcomes relevant and objective?

6. Have all measured outcomes been reported?

7. Has the intervention been defined? (Experimental studies only)

8. Have baseline measurements been taken and separated? (Experimental studies only) 
Monitoring studies were assessed against questions 1 to 6 . Experimental studies were assessed using questions 1 to 8 . The studies were dichotomised into high and low risk of bias based on the overall scoring of yes / no responses. A score of $>4$ / 6 for monitoring studies, or $>5$ / 8 for experimental studies equated to a low risk of bias.

\section{Evidence synthesis and contextualisation}

A maximum likelihood random effects meta-analysis was used to pool results across studies. To facilitate comparison of the effects across different studies, the standardized mean difference (SMD) was calculated so that the 'intervention effect in each study relative to the variability observed in that study' can be assessed (Higgins and Green, 2009).

Models were fitted using the metafor package (Viechtbauer, 2015) in the R statistical environment (R Core Team, 2012). Heterogeneity was quantified using $\mathrm{I}^{2}$, funnel plots and formal tests of funnel plot asymmetry were used to explore publication bias (Higgins et al., 2003). The small sample size and high multidimensionality of the data precluded meaningful exploration of heterogeneity by subgroup analysis or meta-regression (Lortie et al., 2015).

Evidence was contextualised using Bayesian networks $(B N)$ which are graphical models that use conditional probabilities to link variables (Stewart et al., 2015). BNs can be built by combining a range of data sources including empirical evidence and expert elicitation, and are particularly useful for dealing with uncertainty in a transparent way (Landuyt et al., 2013). In contrast to null-hypothesis testing, BNs address problems as systems, focusing on the net changes in the outcome (i.e. the variable) of interest, rather than arbitrary levels of statistical significance. BNs explicitly and mathematically incorporate uncertainty, which typifies data on natural resource utilisation, such as flooding. BNs consist of a graphical representation of (suspected or known) causal relationships which is then supported by the available data and knowledge. The graphical nature of these models conveys complex information in an intuitive manner that is easily interpreted by non-technical managers (Spiegelhalter et al., 2004). 
We parametrised our BN using the results from the meta-analysis and augmented this with contextual information from existing studies by DEFRA (O'Connell et al., 2004) and for English Nature in Upper Seven Catchment (Gilman, 2002), as well as Kirby et al. (1992), which compare the effects of different types of land use of flood risk. The model addressed flood risk, which was considered conditionally dependent on infrastructure density and flood hazard. Flood hazard was a combination of the effects of flood intensity and the frequency of flooding events both of which are conditionally dependent (along with other variables) upon rate of change in storage. Rate of change in storage is conditionally dependent on aspects of catchment landscape and catchment management. The nodes are described in Table 3.

\section{RESULTS}

\section{Literature Search}

The database search (Table 2) returned 156 studies, of which 7 studies were relevant (Figure 1), the majority of which were not UK based and only one was dated within the last 10 years (Table 4$)$.

\section{Meta-Analysis}

The pooled effect size of the 7 studies was $-0.35(95 \% \mathrm{Cl}$ from -0.71 to $0.00, \mathrm{p}<0.001$, Figure 2). Consideration of how big the effect size in relation to zero, as indicated by the lower $95 \% \mathrm{Cl}$. Values of less than 0.25 are interpreted as being below a minimally important difference and values of greater than 0.25 being interpreted as an important difference (Revicki et al., 2008; Copay et al., 2007). This indicates that from the meta-analysis tree cover has a small but statistically significant effect on reducing river discharge.

There was considerable unexplained inconsistency in point estimates, including variation in direction of effect reflected in $\mathrm{I}^{2}(81.91 \%)$ despite the low power of individual studies (Figure 2), with only one study (Robinson et al., 2003) showing that tree planting increased river discharge. The inconsistency in effect is most likely to be due to the different planting systems and different characteristics of catchment areas utilised in the studies. 
Contour enhanced funnel plots aid looking at the distribution of the studies to see whether the areas of missing studies are due to statistical significance (Palmer et al., 2008). If publication bias is present asymmetry around the average effect size and so the funnel occurs, with studies with small or non-significant results (usually in the bottom left-hand corner) typically missing (Sutton et al., 2000). Funnel plot asymmetry (Figure 3) consistent with publication bias was detected and was statistically significant (Egger Test $z=3.056, p=$ 0.002), with studies missing from the right-hand side, which is where studies showing a negative effect of tree planting (i.e. increased river discharge) would sit. It should be noted that there are few studies so this should be interpreted with caution and funnel plot asymmetry is not synonymous with publication bias in every case.

\section{Contextualising the Evidence}

The BN systems model indicates that the primary determinants of flood risk are infrastructure density, reservoirs (storage ponds etc.) and the frequency of flooding (Figure 4). Flood hazard was particularly sensitive to the frequency of flooding, reservoirs, as well as flood intensity, initial condition, soil structure and grip blocking (Figure 5) with flood frequency determined by reservoirs, initial condition, and soil structure (Figure 6). Increasing tree density from low to high only led to a decrease in the probability of high flood risk by $1 \%$ from $16 \%$ to $15 \%$ (Figure 7 ). This implies that increasing tree density is likely to only have a very small effect on flood risk and that multiple interventions are required to be most effective against flood risk.

\section{DISCUSSION}

The results of the systematic review and meta-analysis provide evidence that afforestation has a small and highly variable effect on channel discharge, indicating that the impact of increasing tree cover on flood risk is uncertain. This study highlights a gap in direct evidence for the effect of tree cover on channel discharge. Despite the high number of papers returned by the search, only seven papers met the eligibility criteria. Many of the 156 papers 
that passed the title and abstract review but failed the eligibility criteria were based on modelling and simulations, not empirical data. Only one of the eligible studies was dated within the last decade, indicating an increasing reliance on modelled data.

Of the seven relevant studies from NW Europe, two (Kirby et al., 1992; Hawtree et al., 2015) are considered to represent a high risk of bias, reducing the strength of the evidence. Most studies assume that the effect of the identified intervention (increasing tree cover) is the inverse of the subject intervention of the studies (deforestation). This assumption is a simplification of the effect of the proposed intervention (increasing tree cover); the evidence base for the assertion that tree cover reduces flood risk is further weakened by this assumption. There is considerable inconsistency between studies and funnel plot asymmetry (Figure 3 ) suggests that there is a risk of publication bias although our sample size limits our detection ability. These weaknesses result in high uncertainty, which would reduce with further research.

Synthesis and analysis of existing data on channel discharge with data on afforestation / deforestation could address weaknesses in the existing data set and represents a potential low-cost alternative to long term primary data collection. Flood risk in the UK means that regulatory authorities, such as the Environment Agency and Scottish Environmental Protection Agency manage a network of watercourse monitoring points, collecting channel discharge data from across the country. The active forestry industry in the UK means there is a steady supply of areas of afforestation and deforestation. Synthesis and analysis of this data would represent a relatively low-cost way to address the weaknesses in empirical evidence and facilitate further assessment of the effect of tree cover on channel discharge.

The benefits of further research to address the high uncertainty associated with the existing evidence base for the effects of tree cover on river discharge need to be balanced with the potential contribution to the flood mitigation knowledge base or flood risk mitigation policy and decision making. BN systems modelling indicates that a single intervention (tree planting) has a small effect on channel discharge in a complex system. Given the complex 
1

2

3

4

5

6

7

8

9

system that contributes towards flooding, future research should consider the combination of multiple interventions, rather than just single interventions, i.e. tree planting, as this is likely to highlight which combinations have the greatest effect on reducing channel discharge. The BN model structure and parameterisation are also uncertain, particularly with respect to the impact of outcomes other than channel discharge. This is because the system has not empirically been analysed in totality, as no study examines all the factors simultaneously. The evidence underpinning the linkages is based on expert opinion from the other reports cited and is therefore uncertain. However, BNs offer the capability to quickly update models when and if new empirical data become available. Where nodes have high influence on flood risk we need to ensure that uncertainties are minimised by future research within these topics.

Hydrological models emphasise the importance of surface roughness in increasing lag time with consequent impact on flood peaks. We have not examined this evidence. However, the heuristic framework provided by our $\mathrm{BN}$ and meta-analysis clearly demonstrate the significance of combined effects associated with a combination of variables. The BN supports a holistic approach to flood mitigation indicating that a combination of measures, particularly those associated with infrastructure density and water storage (reservoirs), are effective responses to flood risk.

There are signs that the findings of this study are supported by current shifts in popular discourse on flood risk (Harrabin, 2016a) with more natural and integrated solutions being championed. The BN exposes the over simplification and ineffectiveness of calls for single solution mitigation measures, with the BN emphasising the need for more holistic, multifaceted solutions to address complex hydrological issues such as flooding.

\section{CONCLUSIONS}


Wider environmental and social benefits make tree planting attractive, but advocacy cannot be supported by flood risk mitigation research due to weak direct evidence of the effects of tree cover on river discharge. Further research to address weaknesses could be undertaken via synthesis and analysis of existing data held by a range of regulatory authorities. Considering the variability in tree cover across European countries, this could include a comparison of published flood flow data across catchments with similar hydrological characteristics but with different proportions of tree cover. However, the benefits of further research on a single intervention are limited and alternative evidence-based justifications (for increasing tree cover) should be established and their multiple roles in the landscape considered. The results of this study support investment in integrated catchment management, focusing particularly on measures associated with infrastructure density and water storage (reservoirs), for effective responses to flood risk. 


\title{
ACKNOWLEDGEMENTS
}

Alison Rowntree provided administrative support for the two-day work shop where the analysis underpinning this work was performed. Thanks also to the staff at Alston Youth Hostel for hosting the group and Jack's café in Alston for refreshments and use of WIFI.

\begin{abstract}
AUTHORSHIP
This study was undertaken during two intensive days of data collection, extraction, synthesis and analysis with staff and $\mathrm{PhD}$ students from the Faculty of Science, Agriculture and Engineering at Newcastle University, listed as contributing authors. This activity was facilitated by a core group who contributed to all aspects of work and manuscript production. All listed authors have made substantive contributions to the acquisition and interpretation of the data and manuscript. Core group composition: Jayne Carrick: jayne.carrick@ncl.ac.uk, Friederike Charlotte Bolam: f.c.bolam@ncl.ac.uk, Beth Clark: b.clark@ncl.ac.uk, Dr Matthew Grainger: matthew.grainger@ncl.ac.uk, Dr Gavin Stewart: gavin.stewart@ncl.ac.uk.

All at Newcastle University, Newcastle upon Tyne, Tyne and Wear, NE1 7RU, UK
\end{abstract}




\section{REFERENCES}

BBC News (2010) Carlisle flood defence scheme completed. BBC. http://www.bbc.co.uk/news/10288993 [Accessed: 11 April 2016].

Bernardo, T.M., Rajic, A., Young, I., Robiadek, K., Pham, M.T. and Funk, J.A., 2013. Scoping review on search queries and social media for disease surveillance: a chronology of innovation. Journal of medical Internet research, 15(7).

Bosch, J.M. and Hewlett, J.D. (1982) 'A Review of Catchment Experiments to Determine the Effect of Vegetation Changes on Water Yield and Evapotranspiration', Journal of Hydrology, $55,3-23$.

Centre for Reviews and Dissemination (2009) Systematic Reviews: CRD's guidance for undertaking systematic reviews in health care. University of York, York

CIRIA (2013) Land use management effects on flood flows and sediments - guidance on prediction (C719). CIRIA, London.

Copay, A.G., Subach, B.R., Glassman, S.D., Polly Jr., D.W., Schuler, T.C., 2007.

Understanding the minimum clinically important difference: a review of concepts and methods. Spine J. 7 (5), 541-546.

Dixon, S.J., Sear, D.A., Odoni, N.A., Sykes, T. and Lane, S.N. (2016) The effects of river restoration on catchment scale flood risk and flood hydrology, Earth Surface Processes and Landforms, 997-1008.

Doke,

http://uk.mathworks.com/matlabcentral/fileexchange/7173-grabit [Accessed 3 February 2016]

Gilman, K. (2002) Modelling the effect of land use change in the upper Severn catchment on flood levels downstream. English Nature (Report Number: 471)

Harrabin, R. (2016a) Pickering leaky dams flood prevention scheme 'a success'. BBC. http://www.bbc.co.uk/news/uk-england-york-north-yorkshire-36029197 [Accessed: 13 April 2016].

Harrabin, R. (2016b) Tree planting 'can reduce flooding'. BBC. http://www.bbc.co.uk/news/science-environment-35777927_[Accessed: 27 March 2016].

Hawtree, D., Nunes, J.P., Keizer, J.J., Jacinto, R., Santos, J., Rial-Rivas, M.E., Boulet, A.K., Tavares-Wahren, F. and Feger, K.H. (2015) Time series analysis of the long-term hydrologic 
impacts of afforestation in the Águeda watershed of north-central Portugal. Hydrology and Earth System Sciences, 19(7), 3033-3045.

Higgins JPT, Green S (editors). 2011. Cochrane Handbook for Systematic Reviews of Interventions Version 5.1.0 [updated March 2011]. The Cochrane Collaboration. Available from: www.cochrane-handbook.org.

Higgins, J.P.T., Thompson, S.G., Deeks, J.J. and Altman, D.G. (2003) Measuring inconsistency in meta-analyses. BMJ, 327(7414), 557-560.

Kellens, W., Terpstra, T. and De Maeyer, P. (2013) Perception and Communication of Flood Risks: A Systematic Review of Empirical Research. Risk Analysis: An International Journal, 33(1), 24-49.

Kirby, C., Newson, M.D. and Gilman, K. (1992) Plynlimon research: The first two Decades. Earth Surface Processes and Landforms, 17(6), 635-635.

Koricheva, J., Gurevitch, J. and Mengersen, K. (2013) Handbook of meta-analysis in ecology and evolution. Princeton University Press, Princeton.

KPMG (2015) Flooding economic impact will breach £5bn. KPMG. https://home.kpmg.com/uk/en/home/media/press-releases/2015/12/flooding-economicimpact-will-breach-5bn.html [Accessed: 11 April 2016].

Landuyt, D., Broekx, S., D'Hondt, R., Engelen, G., Aertsens, J. and Goethals, P.L.M. (2013) 'A review of Bayesian belief networks in ecosystem service modelling', Environmental Modelling \& Software, 46, pp. 1-11.

Lortie, C.J., Stewart, G., Rothstein, H. and Lau, J. (2015) How to critically read ecological meta-analyses. Research Synthesis Methods, 6(2), 124-133.

Moher, D., Liberati, A., Tetzlaff, J. \& Altman, D.G. (2009) Preferred reporting items for systematic reviews and meta-analyses: the PRISMA statement. Annals of Internal Medicine, 151(4), 264-269

O'Connell, P.E., Beven, K.J., Carney, J.N., Clements, R.O., Ewen, J., Fowler, H., Harris, G.L., Hollis, J., Morris, J., O'Donnell, G.M., Packman, J.C., Parkin, A., Quinn, P.F., Shepherd, S.C.R.M. and Tellier, S. (2004) Review of impacts of rural land use and management on flood generation: Impact study report (R\&D Technical Report FD2114/TR). Defra/EA.

Palmer, T.M.; Peters, J.L.; Sutton, A.J.; Moreno, S.G. Contour-enhanced funnel plots for meta-analysis. Stata J. 2008, 8, 242. 
$\mathrm{R}$ Core Team (2012). R: A language and environment for statistical computing. $\mathrm{R}$ Foundation for Statistical Computing, Vienna, Austria. Available at: http://www.R-project.org/ Revicki, D., Hays, R.D., Cella, D., Sloan, J., 2008. Recommended methods for determining responsiveness and minimally important differences for patientreported outcomes. J. Clin. Epidemiol. 61 (2), 102-109.

Robinson, M., Cognard-Plancq, A.-L., Cosandey, C., Davidd, J., Durande, P., Fu"hrerf, H.W., Halla, R., Hendriques, M.O., Marc, V., R. McCarthy, M. McDonnell, Martin, C., Nisbet, T., O'Dea, P., Rodgersh, M. and Zollner, A. (2003) Studies of the impact of forests on peak flows and baseflows: a European perspective. Forest Ecology and Management, 186, 85-97. Spiegelhalter, D.J., Abrams, K.R., Myles, J.P. 2004. Bayesian Approaches to Clinical Trials and Health-Care Evaluation.Wiley, England.

Stewart, G.B., Higgins, J.P.T., Schunemann, H. and Meader, N. (2015) The Use of Bayesian Networks to Assess the Quality of Evidence from Research Synthesis: 1. Plos One, 10(4).

Sutton, A.J.; Duval, S.J.; Tweedie, R.L.; Abrams, K.R.; Jones, D.R. Empirical assessment of effect of publication bias on meta-analyses. Br. Med. J. 2000, 320, 1574-1577.

The Guardian (2016) Planting more trees can reduce UK's flood risk, research shows. The Guardian. http://www.theguardian.com/environment/2016/mar/11/planting-more-trees-canreduce-uk-flooding-research-shows [Accessed: 27 March 2016].

Viechtbauer, W. (2010) Conducting meta-analyses in $\{R\}$ with the \{metafor\} package. Journal of Statistical Software, 36 (3), 1-48.

Wilkinson, M.E., Quinn, P.F., Benson, I. and Welton, P. (2010) Runoff management: Mitigation measures for disconnecting flow pathways in the Belford Burn catchment to reduce flood risk, Third International Symposium of the British Hydrological Society: Managing Consequences of a Changing Global Environment. British Hydrological Society, Newcastle University. Available at: https://research.ncl.ac.uk/proactive/belford/papers/BelfordBHS1.pdf.

Williams, J.R., Rose, S.C. and Harris, G.L. (1995) The impact on hydrology and water quality of woodland and setaside establishment on lowland clay soils. Agriculture, Ecosystems and Environment, 54, 215-222. 


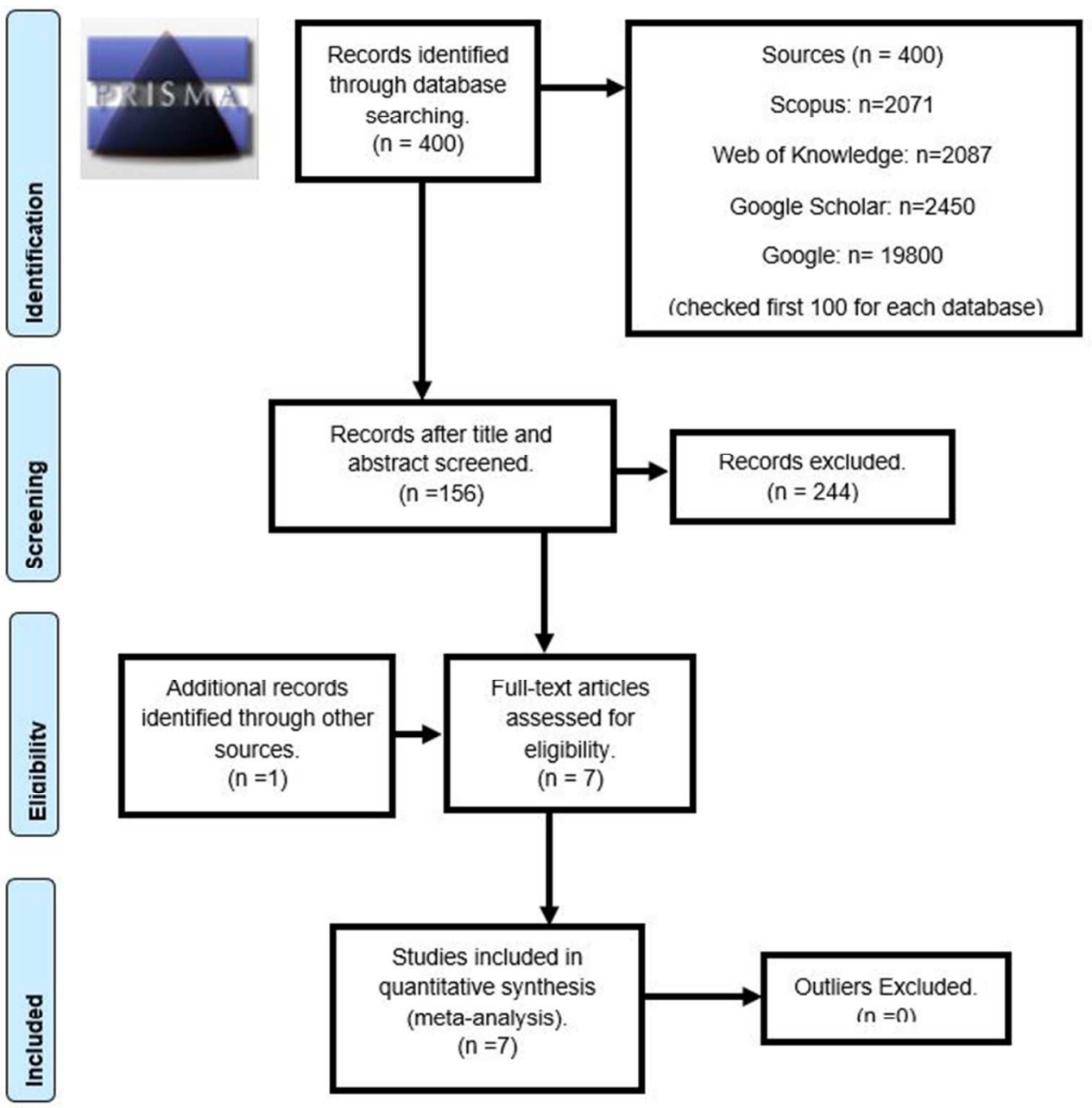

Figure 1: PRISMA flow diagram (Moher et al, 2009) $144 \times 144 \mathrm{~mm}(120 \times 120 \mathrm{DPI})$ 
Figure 2: Forest Plot of effect sizes from 7 eligible studies Bosch and Hewlett, 1982; Hawtree et al., 2015; Kirby et al., 1992; Robinson et al., 2003; Williams et al., 1995). The x-axis is standardized mean difference. The solid vertical line represents the line of no effect; the stippled line and diamond indicate pooled effect sizes for each functional group. Box size is related to sample size; error bars are $95 \%$ confidence intervals. 


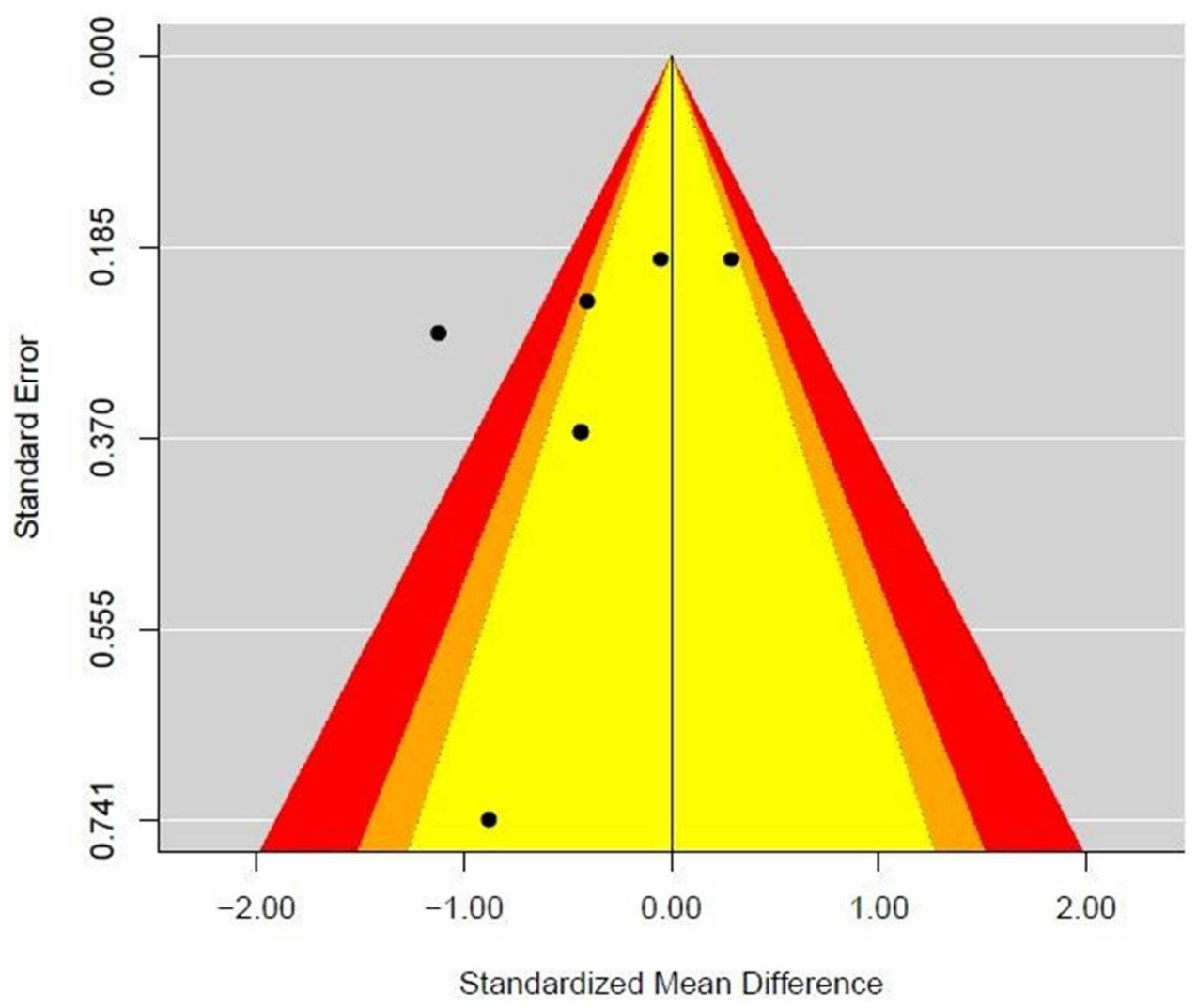

Figure 3: Funnel plot illustrating the distribution of effect sizes (SMD) identified within the seven relevant studies ! + ! +

$175 \times 146 \mathrm{~mm}(96 \times 96 \mathrm{DPI})$ 


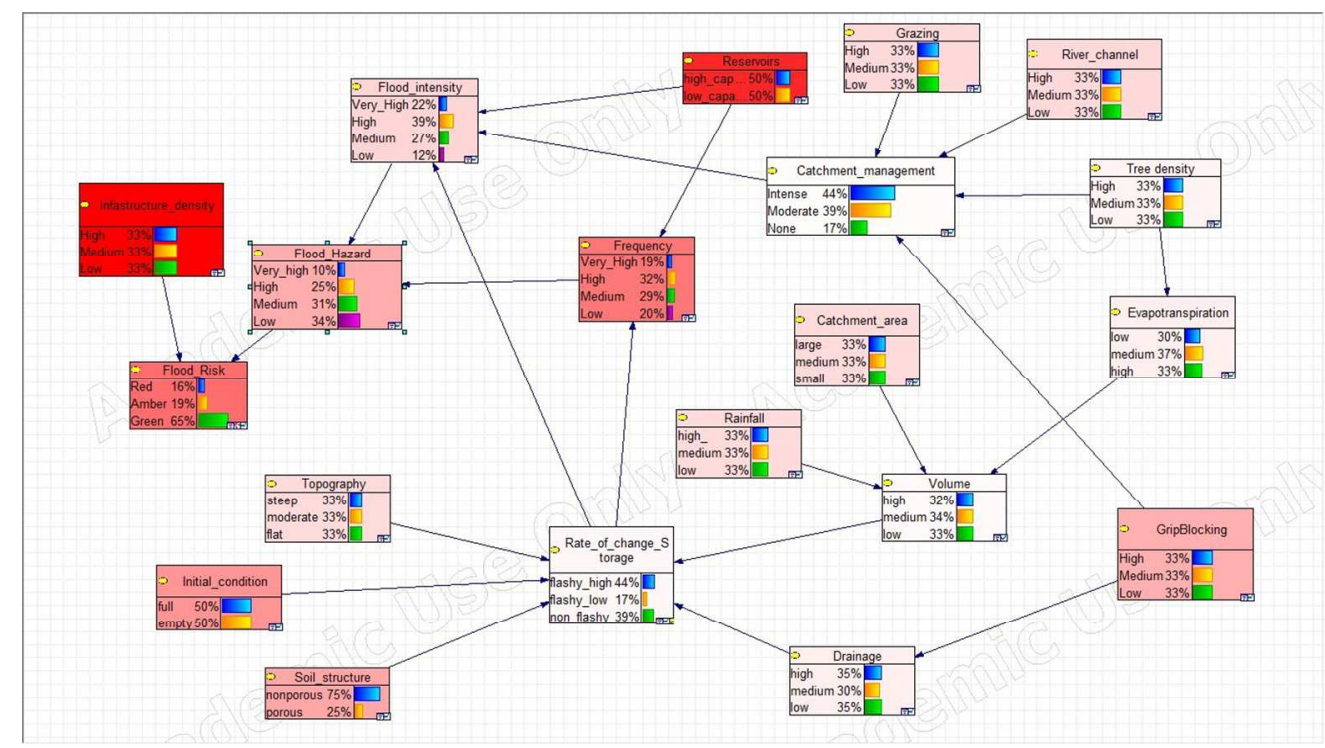

Figure 4: Bayesian Network illustrating flood risk as target. The sensitivity of flood risk to uncertainty in other nodes is indicated by increased shades of red

$361 \times 203 \mathrm{~mm}(96 \times 96$ DPI $)$ 


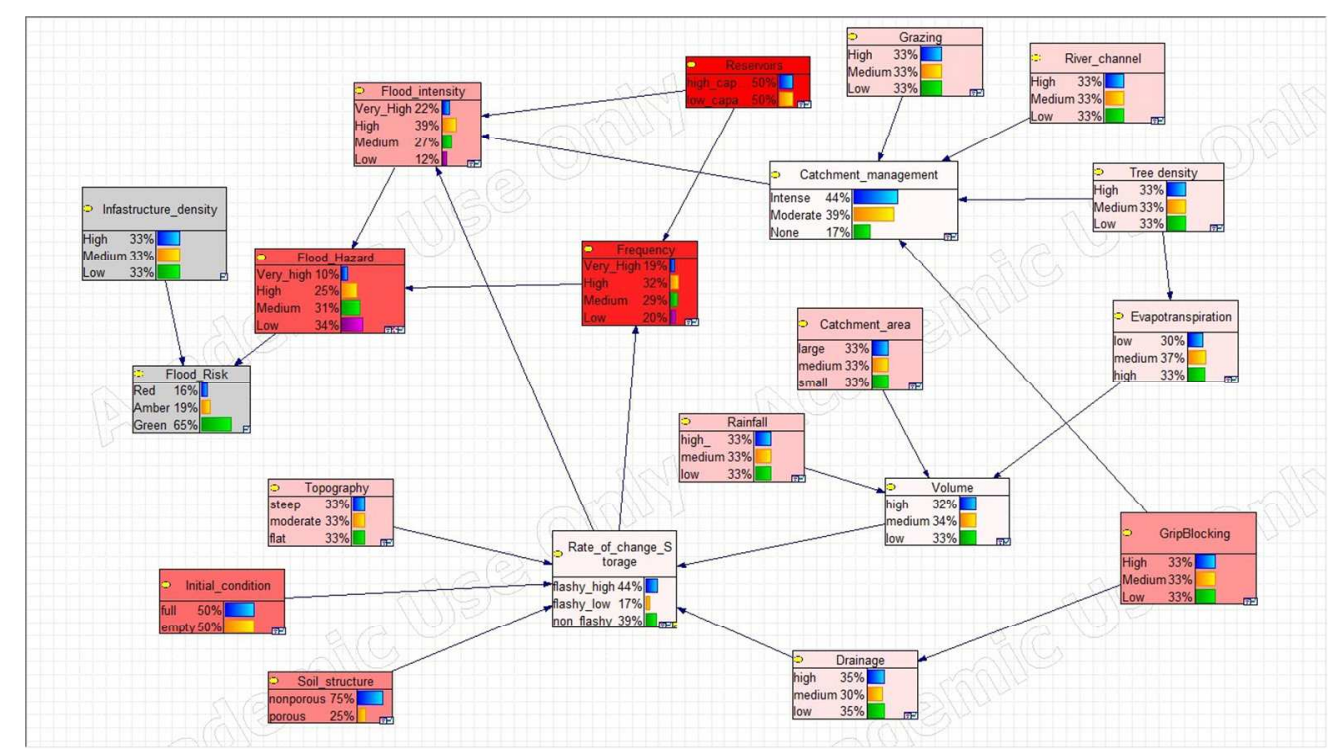

Figure 5: Bayesian Network illustrating flood hazard as target. The sensitivity of flood hazard to uncertainty in other nodes is indicated by increased shades of red.

$361 \times 203 \mathrm{~mm}(96 \times 96 \mathrm{DPI})$ 
Figure 6: Bayesian Network illustrating flooding frequency as the target outcome. The sensitivity of flood frequency to uncertainty in other nodes is indicated by increased shades of red.

$361 \times 203 \mathrm{~mm}(96 \times 96 \mathrm{DPI})$ 

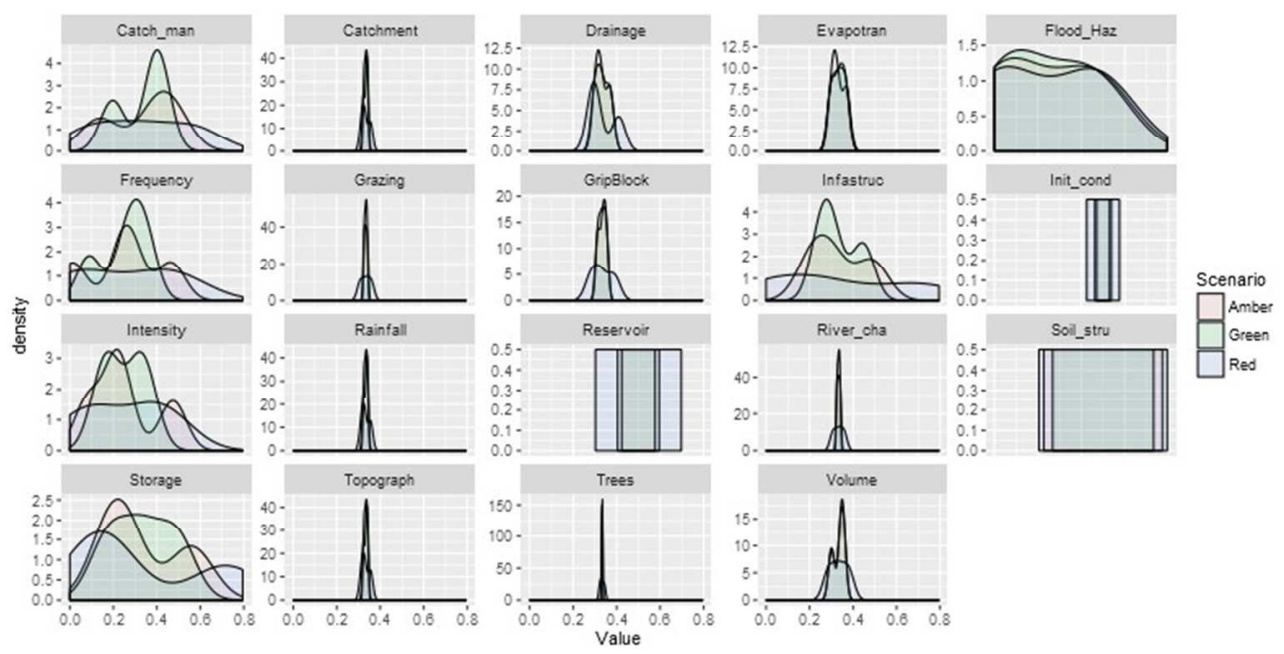

Figure 7: Parameter distributions for low (green), medium (Amber) and high (Red) flood risk scenarios $211 \times 105 \mathrm{~mm}(96 \times 96 \mathrm{DPI})$ 
2

Table 1: Keywords considered for search

\begin{tabular}{ll}
\hline Intervention & $\begin{array}{l}\text { Tree* OR "River basin conservation" OR "Upland management" OR "Natural resource" } \\
\text { OR Reforestation OR Planting OR attenuation OR foliage OR agroforestry OR planting } \\
\text { OR forest OR reforestation OR natural OR shelterbelts OR waterbreak* OR wood* OR } \\
\text { restoration }\end{array}$ \\
\hline AND & \\
\hline Outcome & $\begin{array}{l}\text { Flood* OR "Flood risk" OR Discharge OR "Infiltration rate" OR Flood OR "Run off" OR } \\
\text { "Disaster mitigation" OR "Disaster management" OR "Soil erosion" OR Mitigation OR } \\
\text { reduc* OR manage* OR impact OR effect* OR control OR alleviation OR attenuation OR } \\
\text { climate OR rain* }\end{array}$
\end{tabular}

Table 2: Eligibility criteria

\begin{tabular}{ll}
\hline Study design & $\begin{array}{l}\text { Quantitative empirical data from experimentation or monitoring incorporating a } \\
\text { before/after or treatment/control comparison. }\end{array}$ \\
\hline Sampling universe & Catchments of any size in Europe* \\
\hline Intervention & $\begin{array}{l}\text { Changes in tree cover; afforestation of any type of tree species; Deforestation was also } \\
\text { eligible for inclusion where before and after monitoring was available, with the removal } \\
\text { of trees considered the inverse of tree planting }\end{array}$ \\
\hline Comparators & Land uses other than tree cover; pre- and post-planting, or pre and post deforestation \\
\hline Outcome & Stream / river discharge; where peak discharge was identified this was prioritised \\
\hline & Only English language publications were included \\
\hline
\end{tabular}

${ }^{*}$ One study contained global aggregate data that could not be disaggregated

Table 3. Node description table

\begin{tabular}{|c|c|c|c|c|c|}
\hline Node name & Node description & States & Parents & Relation to parents & Children \\
\hline $\begin{array}{l}\text { Catchment } \\
\text { area }\end{array}$ & $\begin{array}{l}\text { The area of the } \\
\text { catchment }\end{array}$ & $\begin{array}{l}\text { Large / } \\
\text { Medium } \\
\text { Small }\end{array}$ & $\mathrm{N} / \mathrm{A}$ & $\mathrm{N} / \mathrm{A}$ & Volume \\
\hline $\begin{array}{l}\text { Catchment } \\
\text { management }\end{array}$ & $\begin{array}{l}\text { The level of } \\
\text { management in } \\
\text { the catchment } \\
\text { related to water } \\
\text { flow }\end{array}$ & $\begin{array}{l}\text { Intense / } \\
\text { Moderate } \\
\text { / None }\end{array}$ & $\begin{array}{l}\text { Grazing, } \\
\text { River Channel, } \\
\text { Tree density, } \\
\text { Grip blocking }\end{array}$ & $\begin{array}{l}\text { Linear relationship (high } \\
\text { levels of each parent result } \\
\text { in intense Catchment } \\
\text { management) }\end{array}$ & Flood intensity \\
\hline Drainage & $\begin{array}{l}\text { The amount of } \\
\text { drainage } \\
\text { occurring }\end{array}$ & $\begin{array}{l}\text { High / } \\
\text { Medium / } \\
\text { Low }\end{array}$ & Grip blocking & Negative linear relationship & $\begin{array}{l}\text { Rate of } \\
\text { change of } \\
\text { storage }\end{array}$ \\
\hline $\begin{array}{l}\text { Evapo- } \\
\text { transpiration }\end{array}$ & $\begin{array}{l}\text { The rate of } \\
\text { evapotranspiration } \\
\text { in the catchment }\end{array}$ & $\begin{array}{l}\text { High / } \\
\text { Medium / } \\
\text { Low }\end{array}$ & Tree density & Positive linear relationship & Volume \\
\hline Flood hazard & $\begin{array}{l}\text { The probability } \\
\text { that a flood will } \\
\text { occur }\end{array}$ & $\begin{array}{l}\text { Very high } \\
\text { / High / } \\
\text { Medium / } \\
\text { Low }\end{array}$ & $\begin{array}{l}\text { Flood } \\
\text { intensity, } \\
\text { Frequency }\end{array}$ & Positive linear relationship & Flood risk \\
\hline Flood risk & $\begin{array}{l}\text { The probability } \\
\text { that a flood will be } \\
\text { damaging }\end{array}$ & $\begin{array}{l}\text { Red, } \\
\text { Amber, } \\
\text { Green }\end{array}$ & $\begin{array}{l}\text { Flood hazard, } \\
\text { Infrastructure } \\
\text { density }\end{array}$ & $\begin{array}{l}\text { Positive linear relationship } \\
\text { with infrastructure density } \\
\text { having an additive effect - } \\
\text { in area with high density of } \\
\text { infrastructure there is a } \\
\text { greater probability of higher } \\
\text { flood risk. }\end{array}$ & $\mathrm{N} / \mathrm{A}$ \\
\hline
\end{tabular}




\begin{tabular}{|c|c|c|c|c|c|}
\hline Node name & Node description & States & Parents & Relation to parents & Children \\
\hline $\begin{array}{l}\text { Flood } \\
\text { intensity }\end{array}$ & $\begin{array}{l}\text { The intensity of } \\
\text { the flood event }\end{array}$ & $\begin{array}{l}\text { Very high } \\
\text { / High / } \\
\text { Medium / } \\
\text { Low }\end{array}$ & $\begin{array}{l}\text { Reservoirs, } \\
\text { Catchment } \\
\text { management, } \\
\text { Rate of } \\
\text { change of } \\
\text { storage }\end{array}$ & $\begin{array}{l}\text { Positive linear relationship } \\
\text { with catchment } \\
\text { management. Flashy } \\
\text { catchments (Rate of } \\
\text { change of storage) and low } \\
\text { capacity reservoirs } \\
\text { correlate to higher flood } \\
\text { intensity }\end{array}$ & Flood Hazard \\
\hline Frequency & $\begin{array}{l}\text { The frequency of } \\
\text { flood events }\end{array}$ & $\begin{array}{l}\text { Very high } \\
\text { / High / } \\
\text { Medium / } \\
\text { Low }\end{array}$ & $\begin{array}{l}\text { Reservoirs, } \\
\text { Rate of } \\
\text { change of } \\
\text { storage }\end{array}$ & $\begin{array}{l}\text { Linear relationship - low } \\
\text { capacity reservoirs and } \\
\text { flashy rate of storage } \\
\text { correlates to higher } \\
\text { frequency }\end{array}$ & Flood hazard \\
\hline Grip blocking & $\begin{array}{l}\text { Blocking of } \\
\text { drainage on } \\
\text { uplands to } \\
\text { promote upland } \\
\text { bog conservation }\end{array}$ & $\begin{array}{l}\text { High / } \\
\text { Medium / } \\
\text { Low }\end{array}$ & $\mathrm{N} / \mathrm{A}$ & $\mathrm{N} / \mathrm{A}$ & $\begin{array}{l}\text { Catchment } \\
\text { management, } \\
\text { Drainage }\end{array}$ \\
\hline $\begin{array}{l}\text { Infrastructure } \\
\text { density }\end{array}$ & $\begin{array}{l}\text { The density of } \\
\text { infrastructure } \\
\text { (roads, industry, } \\
\text { housing, railways, } \\
\text { etc.) }\end{array}$ & $\begin{array}{l}\text { High / } \\
\text { Medium / } \\
\text { Low }\end{array}$ & N/A & N/A & Flood risk \\
\hline $\begin{array}{l}\text { Initial } \\
\text { condition }\end{array}$ & $\begin{array}{l}\text { The initial state of } \\
\text { the catchment in } \\
\text { terms of water } \\
\text { already in the } \\
\text { system }\end{array}$ & $\begin{array}{l}\text { Full / } \\
\text { Empty }\end{array}$ & $\mathrm{N} / \mathrm{A}$ & $\mathrm{N} / \mathrm{A}$ & $\begin{array}{l}\text { Rate of change } \\
\text { of storage }\end{array}$ \\
\hline Rainfall & $\begin{array}{l}\text { The amount of } \\
\text { rainfall }\end{array}$ & $\begin{array}{l}\text { High / } \\
\text { Medium / } \\
\text { Low }\end{array}$ & $\mathrm{N} / \mathrm{A}$ & $N / A$ & Volume \\
\hline $\begin{array}{l}\text { Rate of } \\
\text { change of } \\
\text { storage }\end{array}$ & $\begin{array}{l}\text { How fast the } \\
\text { catchment } \\
\text { empties }\end{array}$ & $\begin{array}{l}\text { Flashy } \\
\text { high / } \\
\text { Flashy } \\
\text { low / } \\
\text { Non- } \\
\text { flashy }\end{array}$ & $\begin{array}{l}\text { Topography, } \\
\text { Initial } \\
\text { condition, } \\
\text { Soil structure, } \\
\text { Drainage, } \\
\text { Volume, }\end{array}$ & $\begin{array}{l}\text { Positive linear } \\
\text { relationship with all } \\
\text { except drainage (negative } \\
\text { relationship) }\end{array}$ & $\begin{array}{l}\text { Frequency, } \\
\text { Flood intensity }\end{array}$ \\
\hline Reservoirs & $\begin{array}{l}\text { Whether there are } \\
\text { reservoirs in the } \\
\text { catchment (water } \\
\text { storage) }\end{array}$ & $\begin{array}{l}\text { High } \\
\text { capacity } \\
\text { / Low } \\
\text { capacity }\end{array}$ & $\mathrm{N} / \mathrm{A}$ & $\mathrm{N} / \mathrm{A}$ & $\begin{array}{l}\text { Frequency, } \\
\text { Flood intensity }\end{array}$ \\
\hline $\begin{array}{l}\text { River } \\
\text { channel }\end{array}$ & $\begin{array}{l}\text { Engineering on } \\
\text { the river channel } \\
\text { (straightening, } \\
\text { channelizing) }\end{array}$ & $\begin{array}{l}\text { High / } \\
\text { Medium / } \\
\text { Low }\end{array}$ & N/A & $N / A$ & $\begin{array}{l}\text { Catchment } \\
\text { management }\end{array}$ \\
\hline $\begin{array}{l}\text { Soil } \\
\text { structure }\end{array}$ & & & $\mathrm{N} / \mathrm{A}$ & $N / A$ & $\begin{array}{l}\text { Rate of change } \\
\text { of storage }\end{array}$ \\
\hline Topography & $\begin{array}{l}\text { How steep or flat } \\
\text { the catchment is }\end{array}$ & $\begin{array}{l}\text { Steep / } \\
\text { Moderat } \\
\text { e / Flat }\end{array}$ & $\mathrm{N} / \mathrm{A}$ & $N / A$ & $\begin{array}{l}\text { Rate of change } \\
\text { of storage }\end{array}$ \\
\hline Tree density & $\begin{array}{l}\text { The density of } \\
\text { trees in the } \\
\text { catchment }\end{array}$ & $\begin{array}{l}\text { High / } \\
\text { Medium / } \\
\text { Low }\end{array}$ & $\mathrm{N} / \mathrm{A}$ & $N / A$ & $\begin{array}{l}\text { Catchment } \\
\text { management, } \\
\text { Evapotranspirati } \\
\text { on }\end{array}$ \\
\hline
\end{tabular}




\begin{tabular}{|c|c|c|c|c|c|}
\hline Node name & Node description & States & Parents & Relation to parents & Children \\
\hline Volume & $\begin{array}{l}\text { The volume of } \\
\text { water in the } \\
\text { catchment per unit } \\
\text { time }\end{array}$ & $\begin{array}{l}\text { High / } \\
\text { Medium / } \\
\text { Low }\end{array}$ & $\begin{array}{l}\text { Rainfall, } \\
\text { Catchment } \\
\text { area, } \\
\text { Evapotranspir } \\
\text { ation }\end{array}$ & $\begin{array}{l}\text { Positive linear } \\
\text { relationship with } \\
\text { Catchment area and } \\
\text { rainfall. Negative linear } \\
\text { relationship with } \\
\text { Evapotranspiration }\end{array}$ & $\begin{array}{l}\text { Rate of change } \\
\text { of storage }\end{array}$ \\
\hline
\end{tabular}

10

Table 4: Included Studies

\begin{tabular}{|c|c|c|c|}
\hline Source & Comments & $\begin{array}{l}\text { Quality: } \\
\text { Risk of Bias* }\end{array}$ & $\begin{array}{l}\text { Effect Size } \\
(\mathrm{SMD})^{\star *}\end{array}$ \\
\hline $\begin{array}{l}\text { (Bosch and } \\
\text { Hewlett, 1982) }\end{array}$ & $\begin{array}{l}\text { A review of catchment experiments to determine the } \\
\text { effect of vegetation changes on water yield and } \\
\text { evapotranspiration. }\end{array}$ & LOW (4/6) & 1.712 \\
\hline $\begin{array}{l}\text { (Hawtree et al., } \\
\text { 2015) }\end{array}$ & $\begin{array}{l}\text { Time series analysis of the long-term hydrologic } \\
\text { impacts of Eucalyptus afforestation in the Águeda } \\
\text { watershed of north-central Portugal. }\end{array}$ & HIGH (3/6) & 6.448 \\
\hline $\begin{array}{l}\text { (Kirby et al., } \\
1992)\end{array}$ & $\begin{array}{l}\text { Plynlimon research: The first two decades. Wye and } \\
\text { Seven Catchments }\end{array}$ & HIGH (3/6) & 6.448 \\
\hline \multirow{3}{*}{$\begin{array}{l}\text { (Robinson et } \\
\text { al., 2003) }\end{array}$} & $\begin{array}{l}\text { Studies of the impact of forests on peak flows and } \\
\text { baseflows in the Krofdorf Catchment, where } \\
\text { discharge measured before and after tree felling }\end{array}$ & LOW (5/8) & 1.302 \\
\hline & $\begin{array}{l}\text { Studies of the impact of forests on peak flows and } \\
\text { baseflows in St Antonio Portugal, where discharge } \\
\text { before and after felling eucalyptus }\end{array}$ & LOW (6/8) & 0.9011 \\
\hline & $\begin{array}{l}\text { Studies of the impact of forests on peak flows and } \\
\text { baseflows in the Latte basin, where discharge } \\
\text { measured before and after tree felling }\end{array}$ & LOW (5/8) & 0.659 \\
\hline $\begin{array}{l}\text { (Williams et al., } \\
\text { 1995) }\end{array}$ & $\begin{array}{l}\text { Monitoring effect of afforestation on runoff in an } \\
\text { agricultural catchment in Cambridgeshire, UK }\end{array}$ & LOW (4/6) & 0.918 \\
\hline
\end{tabular}

${ }^{*}$ Risk of bias categorised high or low as detailed in section 2.1. Assessment of monitoring studies use six questions, and experimental studies use eight questions.

**SMD: Standardised Mean Difference 